\title{
A framework for a teaching toolkit in entrepreneurship education
}

\author{
Katharina Fellnhofer
}

LUT School of Business and Management, Lappeenranta University of Technology, P.O. Box 20, 53851 Lappeenranta, Finland Email: katharina.fellnhofer@lut.fi

\begin{abstract}
Despite mounting interest in entrepreneurship education (EE), innovative approaches such as multimedia, web-based toolkits including entrepreneurial storytelling have been largely ignored in the EE discipline. Therefore, this conceptual contribution introduces eight propositions as a fruitful basis for assessing a 'learning-through-real-multimedia-entrepreneurialnarratives' pedagogical approach. These recommendations prepare the grounds for a future, empirical investigation of this currently under-researched topic, which could be essential for multiple domains including academic, business and society.
\end{abstract}

Keywords: education; entrepreneurial narratives; entrepreneurial storytelling; entrepreneurship; entrepreneurship education; multimedia teaching material; pedagogical toolkit.

Reference to this paper should be made as follows: Fellnhofer, K. (2017) 'A framework for a teaching toolkit in entrepreneurship education', Int J. Continuing Engineering Education and Life-Long Learning, Vol. 27, No. 3, pp.246-261.

Biographical notes: As Erwin-Schrödinger-Fellow Katharina Fellnhofer is a visiting Researcher at the Lappeenranta University of Technology, Finland. She holds a PhD in Social and Economic Sciences from the University of Innsbruck, Austria. In addition, Katharina Fellnhofer is an Entrepreneur of an Austrian small and medium sized company which is engaged in interdisciplinary European research and innovation projects.

This paper is a revised and expanded version of a paper entitled 'Entrepreneurship education revised: merging a theory-based and action-based framework for entrepreneurial narratives' impact as an awareness-raising teaching tool', presented at 18th International Conference on Innovation and Entrepreneurship in Venice, Italy, 11-12 April 2016.

\section{Introduction}

Because researchers are becoming increasingly interested in entrepreneurship education (EE) this emerging, multidisciplinary topic has been progressing with more high-quality reviews (Rasmussen, 2011; Lorz et al., 2013). While EE is recognised as a vital element for the whole economy among stakeholders (Schumpeter, 1934; Shane and 
Venkataraman, 2000), rising entrepreneurial awareness can act as a cornerstone in this development (e.g., Aviram, 2010; Fretschner and Weber, 2013; Levie et al., 2014). In particular, policy-makers consider EE a crucial basis for future economic development and growth [European Commission (EC), 2013a].

However, according to scholars, further research is required and essential for cultivating effective EE programs (e.g., Lorz et al., 2013; Bae et al., 2014). Several studies have acknowledged inconsistencies in findings regarding EE (Lorz et al., 2013; Rideout and Gray, 2013). Most research analysing EE focuses on the impact of variables such as skills and knowledge, attitudes and perceptions and intentions and performance (e.g., Lorz et al., 2013; Fellnhofer and Kraus, 2015; Fellnhofer, 2015, forthcoming). Despite a few exceptions to the rule (e.g., Oosterbeek et al., 2010), a preponderance of studies corroborate that EE has had a positive impact on individuals (e.g., Sternberg and Wennekers, 2005; Fayolle et al., 2006; Acs and Szerb, 2007; Souitaris et al., 2007). However, research done so far stresses disagreements on how to implement EE in practice (Kozlinska, 2011; Albornoz Pardo, 2013; Lourenço et al., 2013). Overall, there is no comprehensive, pedagogical toolkit to educate people in entrepreneurship (Neck and Greene, 2011). In general, EE challenges traditional, educational methods. In addition, for more than a whole decade there has been a serious call for novel and innovative entrepreneurial teaching techniques (Kuratko, 2003; EC, 2008, 2013c) as well as for more interactive and awareness-raising learning approaches (Kuratko, 2005; Miller et al., 2012; Neck and Greene, 2011; EC, 2013b). In this regard, Gendron (2004) as well as Lautenschläger and Haase (2011) suggest that there should be increased encouragement of entrepreneurs in class. This represents the point of departure for a multimedia approach to spread entrepreneurial narratives productively and resource-efficiently. Such a multimedia approach should utilise Sarasvathy's (2001) theory of effectuation, which has directed lecturers to consider implementing the entrepreneur's personal resources in the curriculum (Fletcher and Watson, 2007; Gibb, 2011). In line with this theory, EE has become continuously subject to a shift towards a more action-oriented, educational approach. This reallocation is based on a consensus in EE research that entrepreneurship is best imparted by using experimental, pedagogical tools (e.g., Fayolle et al., 2006; Noyes and Deligiannidis, 2013; Mayer et al., 2014; Assudani and Kilbourne, 2015). In light of this situation, this paper draws attention to the following research question: Do multimedia entrepreneurial stories constitute an appropriate teaching tool to change perceptions towards entrepreneurship in a positive way?

This qualitative, conceptual paper will first introduce the underlying framework. Within this approach, the propositions will be developed. Finally, a critical discussion will conclude this conceptual paper by taking due account of the limitations and practical and theoretical implications of the framework as well as making recommendations for future research.

\section{The narrative framework}

\subsection{Entrepreneurial narratives for multimedia entrepreneurship education}

From a pedagogical perspective, entrepreneurial role models need not be used in traditional, pedagogical methods such as teacher-learner interactions. Role models can be presented via multimedia through informal narratives with comparatively high value and 
impact with respect to low cost for introducing entrepreneurship (Kuratko, 2005). Stories - or narratives or storytelling - have been shown to have a significant impact on individual perceptions. Bruner (1986) claims that individuals classify familiarity and build reality in two basic ways: propositional judgment and narrative judgment. While the propositional method is based on a cause-to-effect analysis, narrative judgment includes information regarding persons, settings, intentions, and behaviour. Through these elements, narratives create a context to achieve high impact on individuals' perceptions (Stewart, 1997). As indicated by Coles (1989), stories touch us and inspire us to take new paths. Moreover, stories tend to make us more open-minded. Therefore, entrepreneurial narratives are anticipated to be an effective educational approach for EE.

In response to a call to utilise the narrative approach (Johansson, 2004; Hamilton, 2006), research on entrepreneurial behaviour and motivational drivers have already experimented with this direction (Pless, 2007; Essers, 2009; Clarke and Holt, 2010; Flottemesch, 2013; Haley and Boje, 2014). Additionally, Kaminski (2003) recommends employing stories to teach leadership. Furthermore, Watson (2001) proposed using narratives including synthesised content from research and personal experiences to educate managers. The narrative approach has been also used to educate individuals in health and safety issues (Smith, 2005). While Friedman and Prusak (2008) illustrate the transdisciplinary, pedagogic value of narratives, which enhances and shapes our understanding of knowledge management, Gabriel and Connell (2010) discuss the pedagogic potential of narratives as a promising vehicle for management learning. Storytelling has also found its way into strategic management to support the introduction of change aspects and education of human resources (Swap et al., 2001; Sumner, 2005). Because the narrative approach has been successfully implemented in other pedagogical disciplines such as management learning and strategic management, the same is expected to hold true for EE.

The model of entrepreneurial potential elaborated by Krueger and Brazeal's (1994) states that the emphasis on entrepreneurship in classrooms and proliferation of entrepreneurial knowledge, confidence building, and self-efficacy foster entrepreneurship as a socially accepted, highly regarded, personally rewarding and attractive career choice. For this reason, including stories of entrepreneurial role models in curricula show great potential as an effective tool to raise awareness of entrepreneurship as an attractive occupational path (Godsey and Sebora, 2009). Additionally, role models are living confirmation of attractive and achievable objectives, which support individuals to define their self-concept (Akerlof and Kranton, 2000) and develop self-efficacy to embark on an entrepreneurial career (Scherer et al., 1989; Krueger and Carsrud, 1993; Lockwood and Kunda, 1997; De Clercq and Arenius, 2006). Thus, entrepreneurial role models afford great potential to enhance aspirations for entrepreneurial activities (Arenius and De Clercq, 2005; Koellinger et al., 2007).

However, while in recent years entrepreneurship scholars have been encouraged to describe entrepreneurship from a life-story perspective, few scholars such as Robertson and Collins (2003), McAdams and Pals (2006), Engstrom (2012) or Flottemesch (2013) have used a self-narrative approach in EE. Narrative theory is often used for exploring and understanding new concepts. In particular, web-based storytelling has increasingly been used to accommodate several different learning styles (McAdams and Pals, 2006). By interviewing successful entrepreneurs and managers, Hood and Young (1993) suggest that practitioners' recommendations, beliefs and experience should be included in EE curricula. In line with this suggestion and based on Boyles' (2012) work, a conceptual 
model of expected impact variables as basis for this report's propositions is presented in Figure 1. This study supports the grounds for highlighting that narratives enable potential entrepreneurs to:

1 Become motivated about setting up a company with respect to changing attitudes and perception in a positive way.

2 Become convinced in terms of perceived skills and knowledge to devote resources referring to entrepreneurial opportunities, in compliance with the results of Lurtz and Kreutzer (2014) with respect to feasibility.

3 Make key decisions linked to entrepreneurial intentions with respect to behaviour control.

Figure 1 provides the starting point for generating this report's propositions. The variables for studying intended impacts of entrepreneurial narratives using multimedia approaches are outline below.

Figure 1 A conceptual model of expected impact variables

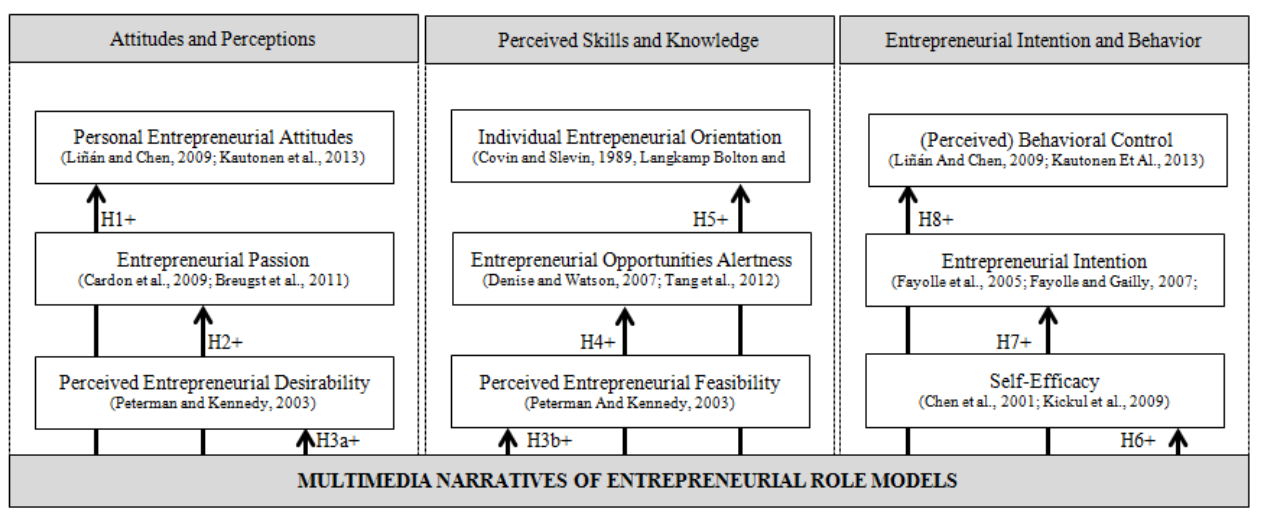

\subsection{Eight impact variables as indicators for an adequate educational vehicle}

\subsubsection{Impact on entrepreneurial attitudes}

The key findings of Shinnar et al. (2009) and earlier results from Carsrud and Olm (1986) state that individuals' views on entrepreneurship often differ. In particular, values and motivations play a crucial role in the intention-behaviour link (Fayolle et al., 2014). The high impact of beliefs about attitude, control, and subjective norms on behaviour mediated by intentions is captured by the Theory of Planned Behavior (TBP) (Ajzen, 1991). According to Ajzen (2011), intention is an individual's eagerness to perform certain behaviour, and attitude refers to a person's evaluation of this intended behaviour. Several researchers have evaluated the impact of EE on individuals' entrepreneurial intentions through attitudes (e.g., Carayannis et al., 2003; Shinnar et al., 2009; Lourenço et al., 2013; Fayolle et al., 2014; Fellnhofer and Kraus, 2015). Several studies discovered that $\mathrm{EE}$ can have a positive impact on entrepreneurial attitudes by increasing the perceived attractiveness of entrepreneurship (e.g., Dickson, 2004; Krueger, 2007; Cheung, 2008; Petridou and Glaveli, 2008; Von Graevenitz et al., 2010). Further, 
researchers have shown that attitudes influence behaviours and behaviours influence attitudes (Brännback et al., 2007; Fretschner and Weber, 2013). This effect of attitude regarding entrepreneurship may vary regionally (Kautonen et al., 2013) or be influenced by culture (Liñán and Chen, 2009). In light of studies highlighting disparities in attitudes among persons who and were and were not participating in EE (Fayolle and Gailly, 2015), we assume that web-based entrepreneurial narratives support individuals in changing their entrepreneurial attitudes. Thus, we predict the following:

Proposition 1 Multimedia entrepreneurial narratives support individuals in changing their attitudes towards entrepreneurship.

\subsubsection{Impact on entrepreneurial passion}

While feelings play a role in entrepreneurship (e.g., Baron, 2008; Foo et al., 2009; Cardon et al., 2012), in general entrepreneurship is linked with the exploration and exploitation of entrepreneurial opportunities (De Carolis and Saparito, 2006). Not only are strong, positive emotions fundamental in academic research on passion (e.g., Carver, 2003), but also in organisational psychology (e.g., Shipton et al., 2006; McMahon, 2009) and in the entrepreneurship literature (e.g., Baum and Locke, 2004; Chen et al., 2009; Cardon et al., 2013). Entrepreneurship is often faced with economic or social shifts and disruptive transformation (Metcalfe, 2004; Christensen et al., 2006), which create the need for continuous passion towards seeking entrepreneurial opportunities, developing ground-breaking products or services, and running initial prototypes while addressing the need for necessary resources (Cardon et al., 2009). Passion is not only desirable for finding a business (Chen et al., 2009), but also necessary for business development and enthusiasm to expand the enterprise (Gundry and Welsch, 2001). Based on these prior findings, we believe that narratives of passionate entrepreneurs can inspire their audience and therefore propose the following:

Proposition 2 Multimedia entrepreneurial narratives support individuals in enhancing their entrepreneurial passion.

\subsubsection{Impact on entrepreneurial perceived desirability and feasibility}

According to the social psychology literature, intentions have been demonstrated to be effective predictors of planned behaviours (Krueger et al., 2000). The existing literature suggests two main antecedents of intentions, i.e. perceptions of desirability and feasibility (e.g., Shepherd and Krueger, 2002; Peterman and Kennedy, 2003; Kuehn, 2008; Armstrong, 2011; Wurthmann, 2014). In order to analyse these dependent drivers pre- and post-watching entrepreneurial narratives, this article suggests investigating these key variables - desirability and feasibility - as well. Many studies such as Ajzen (1991), Shapero (1975) and Shapero and Sokol (1982) discuss the origins of entrepreneurial intentions. In particular, Shapero and Sokol (1982) argue that entrepreneurial intentions originate from feasibility and desirability as well as perceptions and opportunity awareness, which are instrumental in any EE (De Clercq et al., 2013). Nonetheless, whether a generalisation to a narrative EE setting may occur is still an open question (Segal et al., 2005; Lanero et al., 2011). We propose that:

Proposition 3 Multimedia entrepreneurial narratives support individuals in changing their perceived entrepreneurial feasibility and desirability. 


\subsubsection{Impact on opportunity exploration and exploitation}

The exploration and exploitation of entrepreneurial opportunities act as the cornerstone of successful businesses (Sharma and Salvato, 2011; Gaimon and Bailey, 2013). Information and searching for information are key to recognising and exploiting business opportunities (Shane and Venkataraman, 2000; Fiet, 2007), and individuals can learn how to acknowledge patterns required to recognise these potential opportunities (Baron and Ensley, 2006). According to Patel and Fiet (2011), one can improve such recognition of opportunities. A study published by Heinonen and Poikkijoki (2006) related to opportunity discovery, evaluation, and exploitation provides information on applied teaching techniques in EE. This contribution summarises that the entrepreneurial-directed approach appears to be appropriate for broadening individuals' perspectives and developing the skills for entrepreneurial behaviour. Based on Kirzner's (1973, 1979, 1997) work regarding cognition theory and efforts by McMullen and Shepherd (2006), Tang et al. (2012) elaborated a reliable and valid model with three diverse elements of awareness including scanning and searching, relationship and connection, and evaluation and judgment. Given that this alertness scale can serve as a central indicator for effective EE, we propose the following:

Proposition 4 Multimedia entrepreneurial narratives support individuals in facilitating their entrepreneurial alertness related to opportunities.

\subsubsection{Impact on individual entrepreneurial orientation}

The discussion around entrepreneurial orientation (EO) and its implications has received ample scholarly attention in past years (Rauch et al., 2009; Edmond and Wiklund, 2010; Covin and Lumpkin, 2011; Wales et al., 2013). While most academics view the EO construct as a firm-level phenomenon (Covin and Slevin, 1989b; Guth and Ginsberg, 1990; Zahra, 1993; Lumpkin and Dess, 1996; Antoncic and Hisrich, 2001, 2003), it can also be applied to the individual level, although few studies have implemented this approach (e.g., Poon et al., 2006; Joardar and Wu, 2011; Bolton, 2012; Langkamp Bolton and Lane, 2012; Goktan and Gupta, 2013). Based on the effort by Lumpkin and Dess (1996), Langkamp Bolton and Lane (2012) stress the reliability and validity of the used scale with 1,100 individuals. Weaver et al. (2002) applied also the scale of EO. Evidently, individuals are the reasons why enterprises operate entrepreneurially (Joardar and $\mathrm{Wu}, 2011$; Covin and Miller, 2014). Since entrepreneurial role models highlight their EO in their narratives, we assume that entrepreneurs can have an impact on the EO of their audience. In light of the proposed implication, we infer the following:

Proposition 5 Multimedia entrepreneurial narratives support individuals in changing their EO.

\subsubsection{Impact on perceptions of entrepreneurial self-efficacy}

Several researchers focus on evaluating the impact of EE on individuals' intentions to develop a business on traditional antecedents of intentions such as self-efficacy (e.g., Cox et al., 2002; Maritz and Brown, 2013; Piperopoulos and Dimov, 2015). General self-efficacy refers to an individual's estimation regarding his or her general ability to act successfully (Chen et al., 2001). At its heart, self-efficacy is not necessarily about entrepreneurial skills, but rather, one's judgments of possessed skill capability. However, 
self-efficacy is still integral to entrepreneurship as many researchers have found that role models only inspire entrepreneurial intentions if they influence self-efficacy (Chen et al., 2001; Kickul et al., 2009). Because entrepreneurial narratives can increase the probability that individuals will consider an entrepreneurial career, such narratives most likely have a positive effect on individuals' self-efficacy. In line with this argumentation, we assume the following:

Proposition 6 Multimedia entrepreneurial narratives support individuals in facilitating their entrepreneurial self-efficacy.

\subsubsection{Impact on entrepreneurial intentions}

EE is expected to be associated with entrepreneurial self-efficacy, which may increase entrepreneurial intentions (e.g., Wilson et al., 2007; Liao and Gartner, 2008; Bae et al., 2014). There is a well-established research stream stressing that intentions prepare the grounds for founding a company (Liñán and Chen, 2009; Kautonen et al., 2013). Studies that examine EE's impact on entrepreneurial intentions report positive outcomes (Lorz et al., 2013). As discussed, thus, we presume that the same holds true for a new innovative EE approach, and therefore, we predict:

Proposition 7 Multimedia entrepreneurial narratives support individuals in facilitating their entrepreneurial intentions.

\subsubsection{Impact on perceived behavioural control}

In order to assess the effect of EE, most studies accept intention as the immediate determiner of behaviour (e.g., Krueger et al., 2000; Fayolle et al., 2006; Liñán and Chen, 2009). In particular, Kautonen et al. (2013) suggested modified questions and assertions (e.g., "I have applied much effort to activities aimed at starting a business in the last 12 months".) to determine the link between intention and behaviour (Gollwitzer, 1999). In line with this argumentation, the following proposition requires examination when evaluating EE:

Proposition 8 Multimedia entrepreneurial narratives support individuals in facilitating their perceived behavioural control.

\section{Discussion and conclusions}

With respect to recommendations by Lorz et al. (2013), essential elements have been discussed in this conceptual paper as a basis for the future measurement of real entrepreneur narratives as an awareness-raising toolkit using multimedia. Based on the methods of other impact studies (e.g., Kolvereid and Moen, 1997; Wilson et al., 2007; Liao and Gartner, 2008; Olomi and Sinyamule, 2009; Kružić and Bulog, 2010), a structured sampling procedure with an adequate sample size for an ex ante/ex post design represents a further essential requirement for evaluating entrepreneurial narratives as an adequate teaching tool (Lorz et al. 2013). In addition, because most EE studies are carried out at higher educational levels (e.g., Vanevenhoven and Liguori, 2013; Volery et al., 2013; Zhang et al., 2014), a focus on currently under-researched target groups such as students of vocational schools (Lorz et al., 2013) will enrich the academic discussion. 
Only few studies have explored the impact of EE on these groups (Peterman and Kennedy, 2003; Athayde, 2009; Oosterbeek et al., 2010).

As the worldwide dissemination of EE continues (Solomon and Fernald, 1991; Edelman et al., 2008; Joshi and Ganapathi, 2008; Kailer, 2009; Ion and Viorica, 2011; Boyles, 2012) along with growing academic interest in its role and impact (DeJaeghere and Baxter, 2014; Saeed et al., 2014; Sipon and Lope Pihie, 2014; Fayolle and Gailly, 2015), there appears to be little agreement regarding what the content of EE should be as well as how to implement teaching tools in these programs (Honig et al., 2005; Neergaard and Ulhøi, 2007; Edelman et al., 2008). In particular, researchers have paid little attention to the impact of entrepreneurial narratives on individuals (Davidsson, 2006; Pittaway and Cope, 2007; Xavier et al., 2008; de Vries, 2014). In response to this under-researched, phenomenal development and promising topic, this article draws attention to essential impact indicators for a narrative teaching approach within the field of EE privilege. Eight propositions are suggested for a framework to demonstrate that an entrepreneurial narrative approach in EE will produce a positive impact on entrepreneurial attitudes (Proposition 1), entrepreneurial passion (Propositions 2), perceived desirability and feasibility (Propositions 3), alertness to entrepreneurial opportunities (Propositions 4), one's EO (Propositions 5), perceptions of entrepreneurial self-efficacy (Propositions 6), entrepreneurial intention (Propositions 7) and, finally, perceived behavioural control (Propositions 8). Overall, this report stresses that the multimedia entrepreneurial narrative approach affords great potential impact on multiple stakeholders. We strongly suggest that entrepreneurial storytelling could be a useful tool to shape and foster entrepreneurship as an attractive career path. However, this perspective needs to be cast in a formal model with empirical data to ascertain if real entrepreneurial stories support individuals changing their perspectives towards entrepreneurship in a positive way. The proposed framework provides a basis for future research in this discipline.

\section{Acknowledgements}

The author would like to thank the Austrian Science Fund FWF [J3740] for supporting this research project.

\section{References}

Acs, Z. and Szerb, L. (2007) 'Entrepreneurship, economic growth and public policy', Small Business Economics, Vol. 28, Nos. 2/3, pp.109-122.

Ajzen, I. (1991) 'The theory of planned behavior', Organizational Behavior and Human Decision Processes, Vol. 50, No. 2, pp.179-211.

Ajzen, I. (2011) 'The theory of planned behaviour: reactions and reflections', Psychology and Health, Vol. 26, No. 9, pp.1113-1127.

Akerlof, G.A. and Kranton, R.E. (2000) 'Economics and identity', Quarterly Journal of Economics, Vol. 115, No. 3, pp.715-753.

Albornoz Pardo, C. (2013) 'Is business creation the mean or the end of entrepreneurship education? A multiple case study exploring teaching goals in entrepreneurship education', Journal of Technology Management and Innovation, Vol. 8, No. 1, pp.1-10.

Antoncic, B. and Hisrich, R.D. (2001) 'Intrapreneurship: construct refinement and cross-cultural validation', Journal of Business Venturing, Vol. 16, No. 5, pp.495-527. 
Antoncic, B. and Hisrich, R.D. (2003) 'Privatization, corporate entrepreneurship, and performance: testing a normative model', Journal of Developmental Entrepreneurship, Vol. 8, No. 3, pp.197-218.

Arenius, P. and De Clercq, D. (2005) 'A network-based approach on opportunity recognition', Small Business Economics, Vol. 24, No. 3, pp.249-265.

Armstrong, C.E. (2011) 'Thinking and slacking or doing and feeling? Gender and the interplay of cognition and affect in new venture planning', Journal of Developmental Entrepreneurship, Vol. 16, No. 2, pp.213-226.

Assudani, R. and Kilbourne, L. (2015) 'Enabling entrepreneurial minds: using appreciative inquiry as a pedagogical tool for uncovering self- awareness and for generating constructivist learning', Journal of Entrepreneurship Education, Vol. 18, No. 1, pp.65-74.

Athayde, R. (2009) 'Measuring enterprise potential in young people', Entrepreneurship Theory and Practice, Vol. 33, No. 2, pp.481-500.

Aviram, A. (2010) 'Entrepreneurial alertness and entrepreneurial awareness-are they the same?', Academy of Entrepreneurship Journal, Vol. 16, No. 1, pp.111-118.

Bae, T.J., Qian, S., Miao, C. and Fiet, J.O. (2014) 'The relationship between entrepreneurship education and entrepreneurial intentions: a meta-analytic review', Entrepreneurship: Theory and Practice, Vol. 38, No. 2, pp.217-254.

Baron, R.A. (2008) 'The role of affect in the entrepreneurial process', Academy of Management Review, Vol. 33, No. 2, pp.328-340.

Baron, R.A. and Ensley, M.D. (2006) 'Opportunity recognition as the detection of meaningful patterns: evidence from comparisons of novice and experienced entrepreneurs', Management Science, Vol. 52, No. 9, pp.1331-1344.

Baum, J.R. and Locke, E.A. (2004) 'The relationship of entrepreneurial traits, skill, and motivation to subsequent venture growth', Journal of Applied Psychology, Vol. 89, No. 4, pp.587-598.

Bolton, D.L. (2012) 'Individual entrepreneurial orientation: further investigation of a measurement instrument', Academy of Entrepreneurship Journal, Vol. 18, No. 1, pp.91-98.

Boyles, T. (2012) '21st century knowledge, skills, and abilities and entrepreneurial competencies: a model for undergraduate entrepreneurship education', Journal of Entrepreneurship Education, Vol. 15, No. n/a, pp.41-55.

Brännback, M., Krueger, N.F., Carsrud, A.L., Kickul, J. and Elfving, J. (2007) “'Trying' to be an entrepreneur? A 'goal-specific' challenge to the intentions model', Frontiers of Entrepreneurship Research, Vol. 27, No. 6, pp.8-15.

Bruner, E. (1986) 'Ethnography as narrative', in Turner, V. and Bruner, E. (Eds.): The Anthropology of Experience, University of Illinois Press, Chicago.

Carayannis, E.G., Evans, D. and Hanson, M. (2003) 'a cross-cultural learning strategy for entrepreneurship education: outline of key concepts and lessons learned from a comparative study of entrepreneurship students in France and the US', Technovation, Vol. 23, No. 9, pp.757-771.

Cardon, M.S. et al. (2012) 'Exploring the heart: entrepreneurial emotion is a hot topic', Entrepreneurship Theory and Practice, Vol. 36, No. 1, pp.1-10.

Cardon, M.S., Gregoire, D.A., Stevens, C.E. and Patel, P.C. (2013) 'Measuring entrepreneurial passion: conceptual foundations and scale validation', Journal of Business Venturing, Vol. 28, No. 3, pp.373-396.

Cardon, M.S., Wincent, J., Singh, J. and Drnovsek, M. (2009) 'The nature and experience of entrepreneurial passion', Academy of Management Review, Vol. 34, No. 3, pp.511-532.

Carsrud, A. and Olm, K. (1986) 'The success of male and female entrepreneurs: a comparative analysis of the effects of multidimensional achievement motivation and personality traits', in Smilor, R.W. and Kuhn, R.I. (Eds.): Managing Take-off in Fast-Growth Companies, pp.147-162, Praeger, New York.

Carver, C.S. (2003) 'Pleasure as a sign you can attend to something else: placing positive feelings within a general model of affect', Cognition and Emotion, Vol. 17, No. 2, pp.241-261. 
Chen, G., Gully, S.M. and Eden, D. (2001) 'Validation of a new general self-efficacy scale', Organizational Research Methods, Vol. 4, No. 1, pp.62-83.

Chen, X-P., Yao, X. and Kotha, S. (2009) 'Entrepreneur passion and preparedness in business plan presentations: a persuasion analysis of venture capitalists' funding decisions', Academy of Management Journal, Vol. 52, No. 1, pp.199-214.

Cheung, C. (2008) 'Practicing entrepreneurship education for secondary pupils through the operation of a new year stall in Hong Kong', Asia-Pacific Education Researcher, Vol. 17, No. 1, pp.15-31.

Christensen, C.M., Baumann, H., Ruggles, R. and Sadtler, T.M. (2006) 'Disruptive innovation for social change', Harvard Business Review, Vol. 84, No. 12, pp.94-101.

Clarke, J. and Holt, R. (2010) 'Reflective judgement: understanding entrepreneurship as ethical practice', Journal of Business Ethics, Vol. 94, No. 3, pp.317-331

Coles, M.G. (1989) 'Modern mind-brain reading: psychophysiology, physiology, and cognition', Psychophysiology, Vol. 26, No. 3, pp.251-269.

Covin, J.G. and Lumpkin, G.T. (2011) 'Entrepreneurial orientation theory and research: reflections on a needed construct', Entrepreneurship: Theory \& Practice, Vol. 35, No. 5, pp.855-872.

Covin, J.G. and Miller, D. (2014) 'International entrepreneurial orientation: conceptual considerations, research themes, measurement issues, and future research directions', Entrepreneurship: Theory and Practice, Vol. 38, No. 1, pp.11-44.

Covin, J.G. and Slevin, D.P. (1989b) 'Strategic management of small firms in hostile and benign environments', Strategic Management Journal, Vol. 10, No. 1, pp.75-87.

Cox, L., Mueller, S. and Moss, S. (2002) 'The impact of entrepreneurship education on entrepreneurial self-efficacy', International Journal of Entrepreneurship Education, Vol. 1, No. 2, pp.229-245.

Davidsson, P. (2006) Nascent Entrepreneurship: Empirical Studies and Developments, Now Publishers Inc., Boston-Delft, USA.

De Carolis, D.M. and Saparito, P. (2006) 'Social capital, cognition, and entrepreneurial opportunities: a theoretical framework', Entrepreneurship Theory and Practice, Vol. 30, No. 1, pp.41-56.

De Clercq, D. and Arenius, P. (2006) 'The role of knowledge in business start-up activity', International Small Business Journal, Vol. 24, No. 4, pp.339-358.

De Clercq, D., Honig, B. and Martin, B. (2013) 'The roles of learning orientation and passion for work in the formation of entrepreneurial intention', International Small Business Journal, Vol. 31, No. 6, pp.652-676.

de Vries, H.P. (2014) 'Does it really matter? Understanding the impact of engagement and beliefs on immigrant ethnic minority entrepreneurship', Small Enterprise Research, Vol. 21, No. 1, pp.72-81.

DeJaeghere, J. and Baxter, A. (2014) 'Entrepreneurship education for youth in sub-saharan africa: a capabilities approach as an alternative framework to neoliberalism's individualizing risks', Progress In Development Studies, Vol. 14, No. 1, pp.61-76.

Dickson, H.P. (2004) 'Entrepreneurial orientation: the role of institutional environment and firm attributes in shaping innovation and proactiveness', Strategic Management Society Conference, Puerto Rico.

EC (2008) Enterprise and Industry Directorate-General Promotion of SMEs Competiveness Entrepreneurship, Best Procedure Project: Entrepreneurship in Higher Education, Especially in Non-Business Studies, Final Report of the Expert Group, European Commission, Brussels

EC (2013a) Entrepreneurship 2020 Action Plan - Reigniting the Entrepreneurial Spirit in Europe, European Commission, Bruxelles.

EC (2013b) Entrepreneurship 2020 Action Plan. Communication from the Commission to the European Parliament, the Council, the European Economic and Social Committee and the Committee of the Regions. Reigniting the Entrepreneurial Spirit in Europe, EC, Brussels. 
EC (2013c) European Commission: Entrepreneurship Education: A Guide for Educators, Entrepreneurship and Social Economy Unit, Bruxelles.

Edelman, L.F., Manolova, T.S. and Brush, C.G. (2008) 'Entrepreneurship education: correspondence between practices of nascent entrepreneurs and textbook prescriptions for success', Academy of Management Learning and Education, Vol. 7, No. 1, pp.56-70.

Edmond, V. and Wiklund, J. (2010) 'The historic roots of entrepreneurial orientation research', in Lohrke, H.L.F. (Ed.): The Historical Foundations of Entrepreneurship Research, pp.142-160, Edward Elgar Publishers, Cheltenham, UK.

Engstrom, C. (2012) 'An autoethnographic account of prosaic entrepreneurship', Tamara Journal For Critical Organization Inquiry, Vol. 10, No. 1, pp.41-54.

Essers, C. (2009) New Directions in Postheroic Entrepreneurship: Narratives of Gender and Ethnicity, 25th ed., Press DK, Copenhagen Business School.

Fayolle, A. and Gailly, B. (2015) 'The impact of entrepreneurship education on entrepreneurial attitudes and intention: hysteresis and persistence', Journal of Small Business Management, Vol. 53, No. 1, pp.75-93.

Fayolle, A., Gailly, B. and Lassas-Clerc, N. (2006) 'Assessing the impact of entrepreneurship education programmes: a new methodology', Journal of European Industrial Training, Vol. 30, Nos. 8/9, pp.701-720.

Fayolle, A., Liñán, F. and Moriano, J.A. (2014) 'Beyond entrepreneurial intentions: values and motivations in entrepreneurship', International Entrepreneurship and Management Journal, Vol. 10, No. 4, pp.679-689.

Fellnhofer, K. (2015) 'Changing entrepreneurial intention and behaviour: a digital game-based learning environment dedicated to entrepreneurship education', Journal for International Business and Entrepreneurship Development, Vol. 8, No. 4, pp.378-404.

Fellnhofer, K. (forthcoming) 'Game-based entrepreneurship education: impact on attitudes, behaviours and intentions', World Review of Entrepreneurship, Management and Sustainable Development, in press.

Fellnhofer, K. and Kraus, S. (2015) 'Examining attitudes towards entrepreneurship education: a comparative analysis among experts', International Journal of Entrepreneurial Venturing, Vol. 7, No. 4, pp.396-411.

Fiet, J.O. (2007) 'A prescriptive analysis of search and discovery', Journal of Management Studies, Vol. 44, No. 4, pp.592-611.

Fletcher, D.E. and Watson, T.J. (2007) 'Entrepreneurship, management learning and negotiated narratives: "making it otherwise for us - otherwise for them", Management Learning, Vol. 38, No. 1, pp.9-26.

Flottemesch, K. (2013) 'Learning through narratives: the impact of digital storytelling on intergenerational relationships', Academy of Educational Leadership Journal, Vol. 17, No. 3, pp.53-60.

Foo, M-D., Uy, M.A. and Baron, R.A. (2009) 'How do feelings influence effort? An empirical study of entrepreneurs' affect and venture effort', Journal of Applied Psychology, Vol. 94, No. 4, p.1086-1094.

Fretschner, M. and Weber, S. (2013) 'Measuring and understanding the effects of entrepreneurial awareness education', Journal of Small Business Management, Vol. 51, No. 3, pp.410-428.

Friedman, R.S. and Prusak, L. (2008) 'On heuristics, narrative and knowledge management', Technovation, Vol. 28, No. 12, pp.812-817.

Gabriel, Y. and Connell, N.A.D. (2010) 'Co-creating stories: collaborative experiments in storytelling', Management Learning, Vol. 41, No. 5, pp.507-523.

Gaimon, C. and Bailey, J. (2013) 'Knowledge management for the entrepreneurial venture', Production and Operations Management, Vol. 22, No. 6, pp.1429-1438. 
Gendron, G. (2004) Practitioners' Perspectives on Entrepreneurship Education: An Interview with Steve Case, Matt Goldman, Tom Golisano, Geraldine Laybourne, Jeff Taylor, and Alan Webber, Academy of Management Learning \& Education, 1 December, Vol. 3, No. 4, pp.351-352.

Gibb, A. (2011) 'Concepts into practice: meeting the challenge of development of entrepreneurship educators around an innovative paradigm: the case of the International Entrepreneurship Educators' Programme (IEEP)', International Journal of Entrepreneurial Behaviour and Research, Vol. 17, No. 2, pp.146-165.

Godsey, M.L. and Sebora, T.C. (2009) Part IV: Chapter 11: Tell Us Your Story: The Use of Role Model Narratives in Entrepreneurship Education, pp.245-272, Center for Advanced Studies in Management, Current Topics in Management; Vol. 14, Editor M. Afzalur Rahim, New Brunswick (USA) and London: Transaction Publishers.

Goktan, A.B. and Gupta, V.K. (2013) 'Sex, gender, and individual entrepreneurial orientation: evidence from four countries', International Entrepreneurship and Management Journal, Vol. 11, No. 1, pp.95-112.

Gollwitzer, P.M. (1999) 'Implementation intentions: strong effects of simple plans', American Psychologist, Vol. 54, No. 7, pp.493-503.

Gundry, L.K. and Welsch, H.P. (2001) 'The ambitious entrepreneur: high growth strategies of women-owned enterprises', Journal of Business Venturing, Vol. 16, No. 5, pp.453-470.

Guth, W.D. and Ginsberg, A. (1990) 'Guest editors' introduction: corporate entrepreneurship', Strategic Management Journal, Vol. 11, No. 5, pp.5-7.

Haley, U.C.V. and Boje, D.M. (2014) 'Stytelling the internationalization of the multinational enterpriseor', Journal of International Business Studies, Vol. 45, No. 9, pp.1115-1132.

Hamilton, E. (2006) 'Narratives of enterprise as epic tragedy', Management Decision, Vol. 44, No. 4, pp.536-550.

Heinonen, J. and Poikkijoki, S-A. (2006) 'An entrepreneurial-directed approach to entrepreneurship education: mission impossible?', Journal of Management Development, Vol. 25, No. 1, pp.80-94.

Honig, B., Davidsson, P. and Karlsson, T. (2005) 'Learning strategies of nascent entrepreneurs', Journal of Competence-Based Management, Vol. 1, No. 3, pp.67-88.

Hood, J.N. and Young, J.E. (1993) 'Entrepreneurship's requisite areas of development: a survey of top executives in successful entrepreneurial firms', Journal of Business Venturing, Vol. 8, No. 2, pp.115-136.

Ion, P. and Viorica, S. (2011) 'Entrepreneurship education - pillar of sustainable economic development in the third millennium', Quality - Access to Success, Vol. 12, No. Suppl. 2, pp.181-188.

Joardar, A. and Wu, S. (2011) 'Examining the dual forces of individual entrepreneurial orientation and liability of foreignness on international entrepreneurs', Canadian Journal of Administrative Sciences, John Wiley and Sons, Inc., Vol. 28, No. 3, pp.328-340.

Johansson, A.W. (2004) 'Narrating the entrepreneur', International Small Business Journal, Vol. 22, No. 3, pp.273-293.

Joshi, R. and Ganapathi, B. (2008) 'Current status of SMEs and entrepreneurship education and training intervention in select South and South-East Asian countries', ICFAI Journal of Entrepreneurship Development, Vol. 5, No. 1, pp.35-60.

Kailer, N. (2009) 'Entrepreneurship education: empirical findings and proposals for the design of entrepreneurship education concepts at universities in German speaking countries', Journal of Enterprising Culture, Vol. 17, No. 2, pp.1-31.

Kaminski, M. (2003) 'Teaching leadership to union women: the use of stories', Labor Studies Journal, Vol. 28, No. 2, pp.67-77.

Kautonen, T., Gelderen, M. and Fink, M. (2013) 'Robustness of the theory of planned behavior in predicting entrepreneurial intentions and actions', Entrepreneurship: Theory and Practice, Vol. 39, No. 3, pp.655-674. 
Kickul, J., Gundry, L.K., Barbosa, S.D. and Whitcanack, L. (2009) 'Intuition versus analysis? Testing differential models of cognitive style on entrepreneurial self-efficacy and the new venture creation process', Entrepreneurship Theory and Practice, Vol. 33, No. 2, pp.439-453.

Kirzner, I.M. (1973) Competition and Entrepreneurship, University of Chicago Press, Chicago, IL.

Kirzner, I.M. (1979) Perception, Opportunity and Profit, University of Chicago Press, Chicago, IL.

Kirzner, I. (1997) 'Entrepreneurial discovery and the competitive market process: an Austrian approach', J. Econ. Lit., Vol. 35, pp.60-85.

Koellinger, P., Minniti, M. and Schade, C. (2007) “"I think I can, I think I can”: overconfidence and entrepreneurial behavior', Journal of Economic Psychology, Vol. 28, No. 4, pp.502-527.

Kolvereid, L. and Moen, Ø. (1997) 'Entrepreneurship among business graduates: does a major in entrepreneurship make a difference?', Journal of European Industrial Training, Vol. 21, No. 4, pp.154-160.

Kozlinska, I. (2011) 'Contemporary approaches to entrepreneurship education', Journal of Business Management, Vol. 4, No. 1, pp.205-220.

Krueger, N. (2007) 'What lies beneath? The experiential essence of entrepreneurial thinking', Entrepreneurship Theory and Practice, Vol. 31, No. 1, pp.123-138.

Krueger, N., Reilly, M.D. and Carsrud, A.L. (2000) 'Competing models of entrepreneurial intentions', Journal of Business Venturing, Vol. 15, No. 5, pp.411-432.

Krueger, N.F. and Brazeal, D.V. (1994) 'Entrepreneurial potential and potential entrepreneurs', Entrepreneurship: Theory and Practice, Vol. 18, No. 3, pp.91-104.

Krueger, N.F. and Carsrud, A.L. (1993) 'Entrepreneurial intentions: applying the theory of planned behaviour', Entrepreneurship \& Regional Development, Vol. 5, No. 4, pp.315-330.

Kružić, D. and Bulog, I. (2010) 'Students' entrepreneurial characteristics: empirical evidence from Croatia', The Business Review, Cambridge, Vol. 14, No. 2, pp.216-221.

Kuehn, K.W. (2008) 'Entrepreneurial intentions research: implications for entrepreneurship education', Journal of Entrepreneurship Education, Vol. 11, No. 1, pp.87-98.

Kuratko, D.F. (2003) Entrepreneurship Education: Emerging Trends and Challenges for the 21st Century, USASBE, Madison, WI.

Kuratko, D.F. (2005) 'The emergence of entrepreneurship education: development, trends, and challenges', Entrepreneurship: Theory and Practice, Vol. 29, No. 5, pp.577-597.

Lanero, A., Vázquez, J.L., Gutiérrez, P. and García, M.P. (2011) 'The impact of entrepreneurship education in European universities: an intention-based approach analyzed in the Spanish area', International Review On Public and Nonprofit Marketing, Vol. 8, No. 2, pp.111-130.

Langkamp Bolton, D. and Lane, M.D. (2012) 'Individual entrepreneurial orientation: development of a measurement instrument', Education + Training, Vol. 54, Nos. 2/3, pp.219-233.

Lautenschläger, A. and Haase, H. (2011) 'The myth of entrepreneurship education: seven arguments against teaching business creation at universities', Journal of Entrepreneurship Education, Vol. 14, No. n/a, pp.147-161.

Levie, J., Kelley, D.J., Martínez, A.C. and Schøtt, T. (2014) 'The effect of training in starting a business on subsequent entrepreneurial awareness, attitudes, intention and activity: a 37 nation study', International Review of Entrepreneurship, Vol. 12, No. 3, pp.79-102.

Liao, J. and Gartner, W.B. (2008) 'The influence of pre-venture planning on new venture creation', Journal of Small Business Strategy, Vol. 18, No. 2, pp.1-21.

Liñán, F. and Chen, Y.-W. (2009) 'Development and cross-cultural application of a specific instrument to measure entrepreneurial intentions', Entrepreneurship: Theory and Practice, Vol. 33, No. 3, pp.593-617.

Lockwood, P. and Kunda, Z. (1997) 'Superstars and me: predicting the impact of role models on the self', Journal of Personality and Social Psychology, Vol. 73, No. 1, p.91-103.

Lorz, M., Mueller, S. and Volery, T. (2013) 'Entrepreneurship education: a systematic review of the methods in impact studies', Journal of Enterprising Culture, Vol. 21, No. 2, pp.123-151. 
Lourenço, F., Jones, O. and Jayawarna, D. (2013) 'Promoting sustainable development: the role of entrepreneurship education', International Small Business Journal, Vol. 31, No. 8, pp.841-865.

Lumpkin, G.T. and Dess, G.G. (1996) 'Clarifying the entrepreneurial orientation construct and linking it to performance', Academy of Management Review, Vol. 21, No. 1, pp.135-172.

Lurtz, K. and Kreutzer, K. (2014) 'What does your audience expect from you? How entrepreneurs acquire resources through storytelling', Academy of Management Annual Meeting Proceedings, pp.1400-1405.

Maritz, A. and Brown, C. (2013) 'Enhancing entrepreneurial self-efficacy through vocational entrepreneurship education programmes', Journal of Vocational Education and Training, Vol. 65, No. 4, pp.543-559.

Mayer, I., Kortmann, R. and Wenzler, I. (2014) 'Game-based entrepreneurship education: identifying enterprising personality, motivation and intentions amongst engineering students', Journal of Entrepreneurship Education, Vol. 17, No. 2, pp.217-244.

McAdams, D.P. and Pals, J.L. (2006) 'A new big five: fundamental principles for an integrative science of personality', American Psychologist, Vol. 61, No. 3, p.204.

McMahon, G. (2009) 'Positive feelings at work', Training Journal, May, pp.64-68.

McMullen, J.S. and Shepherd, D.A. (2006) 'Entrepreneurial action and the role of uncertainty in the theory of the entrepreneur', Academy of Management Review, Vol. 31, No. 1, pp.132-152.

Metcalfe, J.S. (2004) 'The entrepreneur and the style of modern economics', Journal of Evolutionary Economics, Vol. 14, No. 2, pp.157-175.

Miller, T.L., Wesley, C.L. and Williams, D.E. (2012) 'Educating the minds of caring hearts: comparing the views of practitioners and educators on the importance of social entrepreneurship competencies', Academy of Management Learning and Education, Vol. 11, No. 3, pp.349-370.

Neck, H.M. and Greene, P.G. (2011) 'Entrepreneurship education: known worlds and new frontiers', Journal of Small Business Management, Vol. 49, No. 1, pp.55-70.

Neergaard, H. and Ulhøi, J.P. (2007) Handbook of Qualitative Research Methods in Entrepreneurship, Edward Elgar Publishing, Cheltenham.

Noyes, E. and Deligiannidis, L. (2013) 'Grasping change: visualizing international technology adoption for entrepreneurship education', Journal of Entrepreneurship Education, Special issue, Vol. 16, pp.13-32.

Olomi, D.R. and Sinyamule, R.S. (2009) 'Entrepreneurial inclinations of vocational education students: a comparative study of male and female trainees in Iringa region, Tanzania', Journal of Enterprising Culture, Vol. 17, No. 1, pp.103-125.

Oosterbeek, H., van Praag, M. and Ijsselstein, A. (2010) 'The impact of entrepreneurship education on entrepreneurship skills and motivation', European Economic Review, Vol. 54, No. 3, pp.442-454.

Patel, P.C. and Fiet, J.O. (2011) 'Knowledge combination and the potential advantages of family firms in searching for opportunities', Entrepreneurship Theory and Practice, Vol. 35, No. 6, pp.1179-1197.

Peterman, N.E. and Kennedy, J. (2003) 'Enterprise education: influencing students' perceptions of entrepreneurship', Entrepreneurship: Theory and Practice, Vol. 28, No. 2, pp.129-144.

Petridou, E. and Glaveli, N. (2008) 'Rural women entrepreneurship within co-operatives: training support', Gender in Management: An International Journal, Vol. 23, No. 4, pp.262-277.

Piperopoulos, P. and Dimov, D. (2015) 'Burst bubbles or build steam? Entrepreneurship education, entrepreneurial self-efficacy, and entrepreneurial intentions', Journal of Small Business Management, Vol. 53, No. 4, pp.970-985.

Pittaway, L. and Cope, J. (2007) 'Entrepreneurship education: a systematic review of the evidence', International Small Business Journal, Vol. 25, No. 5, pp.479-510. 
Pless, N. (2007) 'Understanding responsible leadership: role identity and motivational drivers', Journal of Business Ethics, Vol. 74, No. 4, pp.437-456.

Poon, J.M.L., Ainuddin, R.A. and Junit, S.O.H. (2006) 'Effects of self-concept traits and entrepreneurial orientation on firm performance', International Small Business Journal, Vol. 24, No. 1, pp.61-82.

Rasmussen, E. (2011) 'Book review: entrepreneurship education', International Small Business Journal, Vol. 29, No. 6, pp.731-733.

Rauch, A., Wiklund, J., Lumpkin, G. and Frese, M. (2009) 'Entrepreneurial orientation and business performance: an assessment of past research and suggestions for the future', Entrepreneurship: Theory and Practice, Vol. 33, No. 3, pp.761-787.

Rideout, E.C. and Gray, D.O. (2013) 'Does entrepreneurship education really work? A review and methodological critique of the empirical literature on the effects of university-based entrepreneurship education', Journal of Small Business Management, Vol. 51, No. 3, pp.329-351.

Robertson, M. and Collins, A. (2003) 'The video role model as an enterprise teaching aid', Education + Training, Vol. 45, No. 6, pp.331-340.

Saeed, S., Muffatto, M. and Yousafzai, S. (2014) 'A multi-level study of entrepreneurship education among Pakistani university students', Entrepreneurship Research Journal, Vol. 4, No. 3, pp.297-321.

Sarasvathy, S.D. (2001) 'Causation and effectuation: toward a theoretical shift from economic inevitability to entrepreneurial contingency', Academy of Management Review, Vol. 26, No. 2 , pp.243-263.

Scherer, R.F., Adams, J.S., Carley, S. and Wiebe, F.A. (1989) 'Role model performance effects on development of entrepreneurial career preference', Entrepreneurship: Theory and Practice, Vol. 13, No. 3, pp.53-71.

Schumpeter, J.A. (1934) The Theory of Economic Development, Harvard University Press, Cambridge.

Segal, G., Borgia, D. and Schoenfeld, J. (2005) 'The motivation to become an entrepreneur', International Journal of Entrepreneurial Behavior and Research, Vol. 11, No. 1, pp.42-57.

Shane, S. and Venkataraman, S. (2000) 'The promise of entrepreneurship as a field of research', Academy of Management Review, Vol. 25, No. 1, pp.217-226.

Shapero, A. (1975) 'The displaced, uncomfortable entrepreneur', Psychology Today, Vol. 9, No. 11, pp.83-88.

Shapero, A. and Sokol, L. (1982) 'The social dimensions of entrepreneurship', in C. Kent, D. Sexton and K.H. Vesper (Eds.): The Encyclopedia of Entrepreneurship, Prentice-Hall, Englewood Cliffs, NJ, pp.72-90.

Sharma, P. and Salvato, C. (2011) 'Commentary: exploiting and exploring new opportunities over life cycle stages of family firms', Entrepreneurship: Theory and Practice, Vol. 35, No. 6, pp.1199-1205.

Shepherd, D.A. and Krueger, N.F. (2002) 'An intentions-based model of entrepreneurial teams' social cognition', Entrepreneurship: Theory and Practice, Vol. 27, No. 2, p.167.

Shinnar, R., Pruett, M. and Toney, B. (2009) 'Entrepreneurship education: attitudes across campus', Journal of Education For Business, Vol. 84, No. 3, pp.151-159.

Shipton, H.J., West, M.A., Parkes, C.L., Dawson, J.F. and Patterson, M.G. (2006) 'When promoting positive feelings pays: aggregate job satisfaction, work design features, and innovation in manufacturing organizations', European Journal of Work and Organizational Psychology, Vol. 15, No. 4, pp.404-430.

Sipon, M. and Lope Pihie, Z.A. (2014) 'The role of entrepreneurship education in human resource development and its relationships with teacher's pedagogical content knowledge practices', Proceedings of the European Conference on Management, Leadership and Governance.

Smith, S. (2005) 'Preaching or teaching: the use of narrative in safety training', Occupational Hazards, Vol. 64, No. 4, pp.19-24. 
Solomon, G.T. and Fernald Jr, L.W. (1991) 'Trends in small business management and entrepreneurship education in the United States', Entrepreneurship: Theory and Practice, Vol. 15, No. 3, pp.25-39.

Souitaris, V., Zerbinati, S. and Al-Laham, A. (2007) 'Do entrepreneurship programmes raise entrepreneurial intention of science and engineering students? The effect of learning, inspiration and resources', Journal of Business Venturing, Vol. 22, No. 4, pp.566-591.

Sternberg, R. and Wennekers, S. (2005) 'Determinants and effects of new business creation using global entrepreneurship monitor data', Small Business Economics, Vol. 24, No. 3, pp.193-203.

Stewart, I. (1997) 'Teaching accounting ethics: the power of narrative', Accounting EducationGreenwich, Vol. 2, No. 2, pp.173-185.

Sumner, J. (2005) 'Storytelling puts knowledge in context', Knowledge Management Review, Vol. 8, No. 3, pp.2-6.

Swap, W., Leonard, D. and Mimi Shields, L.A. (2001) 'Using mentoring and storytelling to transfer knowledge in the workplace', Journal of Management Information Systems, Vol. 18, No. 1, pp.95-114.

Tang, J., Kacmar, K.M.M. and Busenitz, L. (2012) 'Entrepreneurial alertness in the pursuit of new opportunities', Journal of Business Venturing, Vol. 27, No. 1, pp.77-94.

Vanevenhoven, J. and Liguori, E. (2013) 'The impact of entrepreneurship education: introducing the entrepreneurship education project', Journal of Small Business Management, Vol. 51, No. 3, pp.315-328.

Volery, T., Müller, S., Oser, F., Naepflin, C. and Rey, N. (2013) 'The impact of entrepreneurship education on human capital at upper-secondary level', Journal of Small Business Management, Vol. 51, No. 3, pp.429-446.

Von Graevenitz, G., Harhoff, D. and Weber, R. (2010) 'Author's personal copy: the effects of entrepreneurship education', Journal of Economic Behavior \& Organization, Vol. 76, pp.90-112.

Wales, W.J. et al. (2013) 'Nonlinear effects of entrepreneurial orientation on small firm performance: the moderating role of resource orchestration capabilities', Strategic Entrepreneurship Journal, Vol. 7, No. 2, pp.93-121.

Watson, T.J. (2001) 'Beyond managism: negotiated narratives and critical management education in practice', British Journal of Management, Vol. 12, No. 4, pp.385-396.

Weaver, K.M., Dickson, P.H., Gibson, B. and Turner, A. (2002) 'Being uncertain: the relationship between entrepreneurial orientation and environmental uncertainty', Journal of Enterprising Culture, Vol. 10, No. 2, pp.87-105.

Wilson, F., Kickul, J. and Marlino, D. (2007) 'Gender, entrepreneurial self-efficacy, and entrepreneurial career intentions: implications for entrepreneurship education', Entrepreneurship Theory and Practice, Vol. 31, No. 3, pp.387-406.

Wurthmann, K. (2014) 'Business students' attitudes toward innovation and intentions to start their own businesses', International Entrepreneurship and Management Journal, Vol. 10, No. 4, pp.691-711.

Xavier, M.J., Raja, J. and S, U.N. (2008) 'Impact assessment of a rural women's micro entrepreneurship project using path analysis models', IIMB Management Review, Indian Institute of Management Bangalore, Vol. 20, No. 2, pp.215-227.

Zahra, S.A. (1993) 'Environment, corporate entrepreneurship, and financial performance: a taxonomic approach', Journal of Business Venturing, Vol. 8, No. 4, pp.319-341.

Zhang, Y., Duysters, G. and Cloodt, M. (2014) 'The role of entrepreneurship education as a predictor of university students' entrepreneurial intention', International Entrepreneurship and Management Journal, Vol. 10, No. 3, pp.623-641. 